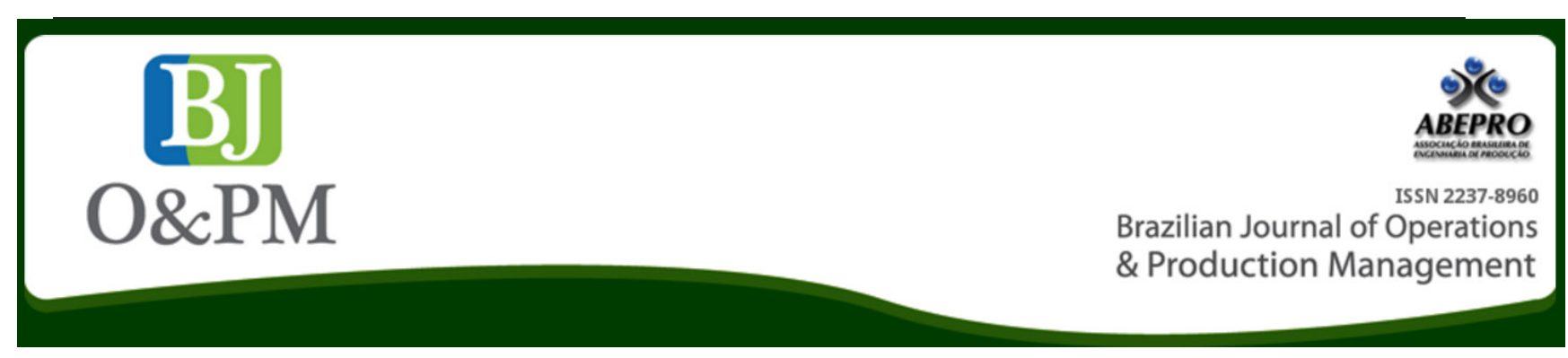

\title{
DAIRY PRODUCTION DIAGNOSIS FROM THE PERSPECTIVE OF BUSINESS ECOSYSTEM: STATE OF THE ART IN 2016
}

Andrei Bonamigo ${ }^{a}$; Helio Aisenberg Ferenhof ${ }^{a}$; Fernando Antonio Forcellini ${ }^{\mathrm{a}}$

${ }^{\text {a }}$ Federal University of Santa Catarina (UFSC) - Florianópolis, SC, Brazil

\begin{abstract}
In the pursuit of identify ways for a better understanding the barriers of the dairy production system, we sought to diagnose them from the perspective of the business ecosystem concept, through a systematic literature review. Thus, we use content analysis to serve as the basis for analysis and discussion of the barriers of dairy production. Resulting a total of fifteen barriers, properly presented and discussed. In addition, we provide some insights to mitigate these barriers. The study presents contribution to the development of dairy production by providing assistance to develop strategies for producers' cooperatives, government agencies, milk producers, hulling industries products from milk. Based on the perspective of the business ecosystem is possible to have a broader view of the scenario where dairy production occurs and recognize the barriers of dairy production system. And once identified these barriers, it is possible to devise strategies to eliminate or mitigate these barriers.
\end{abstract}

Keywords: dairy chain; business ecosystem; barriers; value co-creation; dairy production. 
Brazilian Journal of Operations \& Production Management Volume 14, Número 1, 2017, pp. 74-80 DOI: 10.14488/BJOPM.2017.v14.n1.a8

\section{INTRODUCTION}

Approximately 150 million production units worldwide are involved in dairy production. In most developing countries, milk is produced by small farmers, and dairy production contributes to the livelihoods of household food security and nutrition (FAO, 2016).

The dairy production activities have many positive aspects, but it is necessary to overcome some obstacles, such as low milk quality and low productivity, to be development of the activity (RODRIGUES et ALBAN, 2013; WINCK, 2011).

In the pursuit of identify ways for a better understanding the barriers and relationships in the dairy production system, we sought theoretical support in the business ecosystem concept. The business ecosystem comprises a set of organizations that co-evolve through co-creation of value in a business environment. This analogy is related to the comparison of biological ecosystems (MOORE, 1993; GALATEANU et AVASILCAI, 2013).

In the face of problems, this article aims to make a diagnosis of dairy production, in order to identify the development barriers, from the perspective of the business ecosystem. By examining the nature of relationships within the dairy production, it is possible to identify ways they can improve the livelihoods of farmers, trading standards, efficiency and performance of the entire chain (XHOXHI et al., 2014).

In this sense, the importance of this study is given by a better understanding of the players that compose the dairy business ecosystem. Once the interaction between them is better understood, and alsothe barriers that surround it, it is possible to think and plan actions mitigating these obstacles. In addition, the holistic view permits a whole system to understand, and this helps in structuring and designing strategies to drive the sector development.

For Bonamigo et al. (2016), the business ecosystem concept applicability in the dairy production system is presented as means to manage this system to its development. Both biological ecosystems, as the business ecosystems have a community that lives or works in specific environmental conditions.

These systems are based on fair relations between the partners. Of which the business ecosystem, relates through the formation of a business platform, consisting of: universities, research centers, public organizations, unions, suppliers, consumers, and others who can exchange knowledge and encourage the co-creation of value between the actors who form the business platform (GALATEANU et AVASILCAI, 2013; MOORE, 1993, PELTONIEMI et VUORI, 2005).
The holistic approach that the business concept ecosystem introduces, boosts the knowledge and/or resources exchange, which an actor acting individually would be restricted to themselves and should work harder to compensate for their limitations in order to develop the dairy production.

As the problematic presented regarding the dairy agribusiness system exposes evidence that the development of the sector is related to management of the actors included in this environment and their relationships. Based on that, we come with the following research question: What are the barriers that limit the development of dairy production? In order to answer it, this study aims to diagnose dairy production in order to list the main barriers of production, so further studies can be carried to mitigate the barriers outlined.

\section{METHODOLOGY}

The methodology used for the study comprises two stages. The first was conducted a systematic literature review, to recognize the state of the art on the subject. Then, the content analysis composed by 1) Pre-analysis; 2) Exploration material or coding and; 3 ) treatment of results, inference and interpretation, as recommended by Bardin (2011) was performed as detailed in the following.

Our systematic review followed Jesson et al. (2011) six principles for systematic reviews, which are as follows:

(1) Mapping the field through a scoping review.

(2) Comprehensive search.

(3) Quality assessment, which comprises the reading and selection of the papers.

(4) Data extraction, which refers to the collection of relevant data and the capturing of the data into a pre-designed extraction sheet.

(5) Synthesis, which comprises the synthesis of the extracted data to show the known and to provide the basis for establishing the unknown.

(6) Write-up.

First, we mapped the literature by composing the research questions of interest, the keywords, and a set of inclusion and exclusion criteria. The query for this research was ([milk OR "dairy chain" OR "agribusiness milk" OR "dairy farms"] AND [risk OR threats]). The inclusion criteria were peerreviewed academic papers in English, Portuguese languages, and the databases used were Emerald, Scopus, Scielo, and Web of Science, which executes the query on the topic, keywords, or abstracts. We excluded gray literature such as reports, books, and non-academic research, and content in languages other than the presented ones. Furthermore, a spreadsheet was produced consisting of key aspects related to the diagnosis of daily production. 
Second, one of us accessed the four databases and searched using query resulted by the combinations of the keywords set. We seek for combinations of these keywords in the title, keywords and abstract. We highlight that the search on the databases were made on March 14, 2016. And returned 1229 documents where 90 where duplicated, resulting into 1139 papers.

Third, each of us physically examined the title, abstracts and keywords of the respective papers to make sure that they actually fell within our scope of interest. This reduced the number of documents to 37 , which fulfilled our criteria and were then analyzed.

Fourth, the 37 papers were read by each of the authors, and coded according to the content analysis criteria as specified by (BARDIN, 2011).

Fifth, in the sequence, the individual data were synthesized into one single spread sheet. Later, each instigator independently worked across the merged sheet to check for consistency regarding the coding of the context unit and record unit. Our different understandings were shared and discussed during our discussion cycles. These discussion cycles led to a further reduction of the number of papers. At the end, 9 empirical papers formed the basis for analysis (Table 1).

Sixth, the final stage of our review process was devoted to the write-up of the findings.

\section{RESULTS AND DISCUSSION}

From the analysis of the articles, three units records were generated, and classified the context units, totaling fifteen context units, as can be seen on Table 2 .
Based on the content analysis, we discuss each of the three record units in order to identifying barriers and factors that influence the diary activity.

\subsection{Barriers limiting the development of dairy activity}

From the content analysis, it was possible to identify barriers for the development of dairy farming. Figure 1 represents the distribution of the characterization of the barriers in each of the record units, and the source of this information.

Regarding the barriers, three subsequent register units were created: 1) Lack of cooperation between actors of the chain, 2) milk quality deficiencies, and 3) Productivity limitations.

The unit of context revealed that the barriers related lack of cooperation between the actors of dairy production as one of the main issues. And to mitigate or eliminate it, became clear the need for improvement of network innovation (Dolinska et d'Aquino 2016; Smits et Kuhlmann 2004). It also shows that the coupling between the actors of the same level, as is the case of producers, and multiple actors that exchange knowledge in the chain can be harmful if it is disconnected (EASTWOOD et al., 2012). This is what prevents actors to co-create and innovate in the milk production environment and overcome the adverse effects of the activity. Given the above, it became clear the need in managing of the actors in these environment (LAMPRINOPOULOU et al., 2014; KILELU et al., 2013).

This lack of management among the participants of the business environment prevents them to obtain substantial economic rewards. If there is a management of these actors there will be more likely to generate potential

Table 1. Resulting bibliographic portfolio

\begin{tabular}{|c|c|c|c|c|}
\hline Code & Author & Year & Title & Journal \\
\hline 1 & Somda et al. & 2005 & $\begin{array}{l}\text { Characteristics and economic viability of milk production in the smallholder farming systems in } \\
\text { The Gambia }\end{array}$ & $\begin{array}{l}\text { Agricultural } \\
\text { Systems }\end{array}$ \\
\hline 2 & Novo, et al. & 2013 & $\begin{array}{l}\text { Feasibility and competitiveness of intensive smallholder dairy farming in Brazil in comparison } \\
\text { with soya and sugarcane: Case study of the Balde Cheio Programme }\end{array}$ & $\begin{array}{l}\text { Agricultural } \\
\text { Systems }\end{array}$ \\
\hline 3 & Eastwood et al. & 2012 & $\begin{array}{l}\text { Networks of practice for co-construction of agricultural decision support systems: Case studies } \\
\text { of precision dairy farms in Australia }\end{array}$ & $\begin{array}{l}\text { Agricultural } \\
\text { Systems }\end{array}$ \\
\hline 4 & Saenger et al. & 2013 & $\begin{array}{l}\text { Contract farming and smallholder incentives to produce high quality: experimental evidence } \\
\text { from the Vietnamese dairy sector }\end{array}$ & $\begin{array}{l}\text { Agricultural } \\
\text { Economics }\end{array}$ \\
\hline 5 & $\begin{array}{l}\text { Dolinska et } \\
\text { d'Aquino }\end{array}$ & 2016 & $\begin{array}{l}\text { Farmers as agents in innovation systems. Empowering farmers for innovation through } \\
\text { communities of practice }\end{array}$ & $\begin{array}{l}\text { Agricultural } \\
\text { Systems }\end{array}$ \\
\hline 6 & $\begin{array}{l}\text { Lamprinopoulou } \\
\text { et al. }\end{array}$ & 2014 & $\begin{array}{l}\text { Application of an integrated systemic framework for analysing agricultural innovation systems } \\
\text { and informing innovation policies: Comparing the Dutch and Scottish agrifood sectors }\end{array}$ & $\begin{array}{l}\text { Agricultural } \\
\text { Systems }\end{array}$ \\
\hline 7 & Kilelu et al. & 2013 & $\begin{array}{l}\text { Unravelling the role of innovation platforms in supporting co-evolution of innovation: } \\
\text { Contributions and tensions in a smallholder dairy development programme }\end{array}$ & $\begin{array}{l}\text { Agricultural } \\
\text { Systems }\end{array}$ \\
\hline 8 & Valeeva et al. & 2007 & Modeling farm-level strategies for improving food safety in the dairy chain & $\begin{array}{l}\text { Agricultural } \\
\text { Systems }\end{array}$ \\
\hline 9 & Colurcio et al. & 2012 & Asymmetric relationships in networked food innovation processes & $\begin{array}{l}\text { British Food } \\
\text { Journal }\end{array}$ \\
\hline
\end{tabular}


Brazilian Journal of Operations \& Production Management Volume 14, Número 1, 2017, pp. 74-80 DOI: 10.14488/BJOPM.2017.v14.n1.a8

Table 2. Limiters of dairy production

\begin{tabular}{|c|c|c|}
\hline Record Unit & Context Unit & Frequency \\
\hline \multirow{10}{*}{$\begin{array}{l}\text { Lack of } \\
\text { cooperation } \\
\text { between the } \\
\text { chain actors }\end{array}$} & A3 - Lack of coupling ability between the actors of the network. Each player is limited to its capacity for innovation. & \multirow{10}{*}{10} \\
\hline & A3 - Interaction through technological innovation systems for knowledge exchange. & \\
\hline & $\begin{array}{l}\text { A5 - Farmers do not have enough interaction with other actors, and this is presented as an element that hampers } \\
\text { innovation }\end{array}$ & \\
\hline & A5 - Disconnected networks that provide access to innovation and resources & \\
\hline & A5- Limited access to knowledge sources. & \\
\hline & A5- Interventions based on multi-agent settings, such as innovation platforms, you can build the business development. & \\
\hline & A6- Need for active interaction in a wider network of actors involved. & \\
\hline & A7 - Lack of value chain interaction reinforcement, to increase productivity at farm level. & \\
\hline & A9 - The network innovation has benefits that can include skills, enhancing learning, new ideas and co-development. & \\
\hline & $\begin{array}{l}\text { A9 - Continuous cooperation with corporate clients triggers a process of knowledge creation that leads to learning and } \\
\text { improvement through innovation. }\end{array}$ & \\
\hline \multirow{3}{*}{$\begin{array}{l}\text { Milk quality } \\
\text { deficiencies }\end{array}$} & $\begin{array}{l}\text { A2 - Introduction of technologies for intensive dairy production provides a viable option for small farmers with farms } \\
\text { of medium size. }\end{array}$ & \multirow{3}{*}{3} \\
\hline & $\begin{array}{l}\text { A4 -Dairy industry demand new and efficient ways for high-quality source material. The use of contracts is a common } \\
\text { practice to improve the quality of milk. }\end{array}$ & \\
\hline & $\begin{array}{l}\text { A8 - Improving food security in hygienic conditions, is linked to good practice, cleaning and disinfection, as well as } \\
\text { monitoring programs, they contribute to the improvement and performance of dairy farming. }\end{array}$ & \\
\hline \multirow{2}{*}{$\begin{array}{l}\text { Productivity } \\
\text { limitations }\end{array}$} & A1 - Increased productivity includes the lack of improved technology and weak institutional support. & \multirow[b]{2}{*}{2} \\
\hline & $\begin{array}{l}\text { A2 - Introduction of technologies for intensive dairy production provides a viable option for small farmers with farms } \\
\text { of medium size. }\end{array}$ & \\
\hline
\end{tabular}

Source: Research data

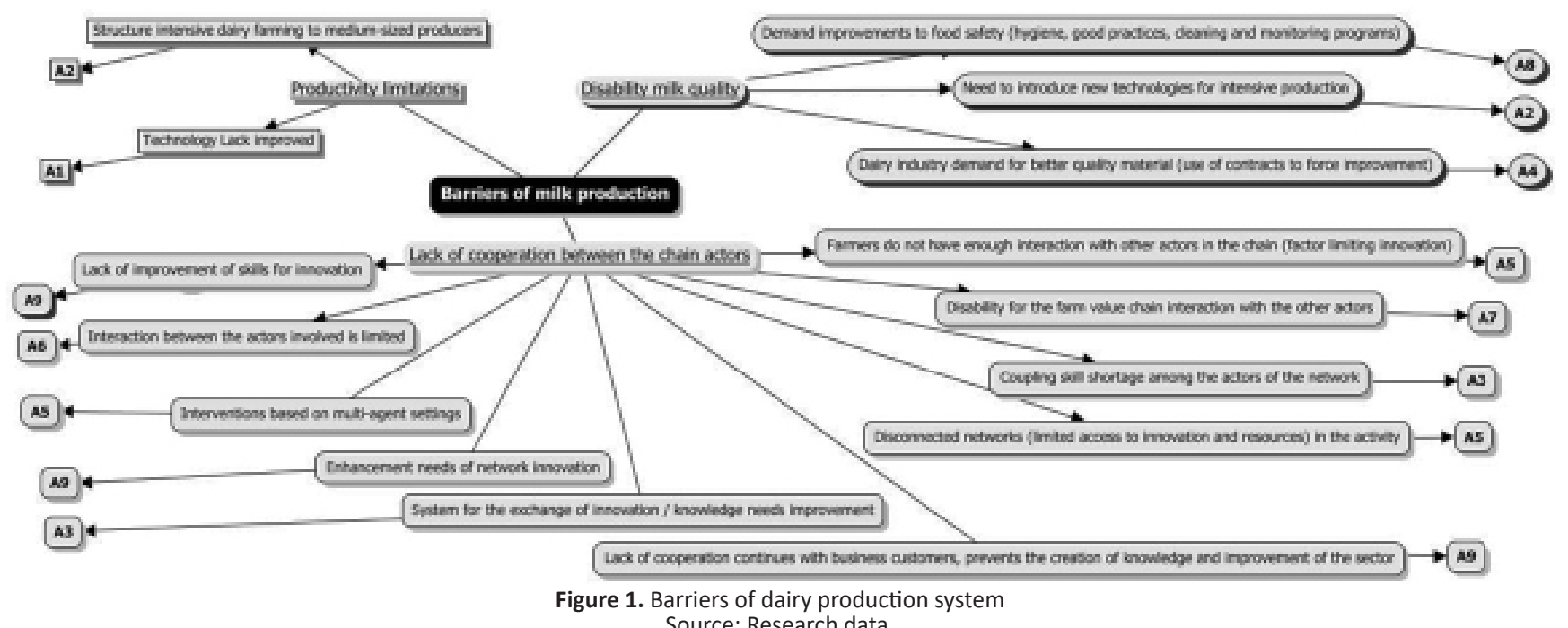

innovations in dairy production. This innovation potential can be stimulated by specific factors such as technological advances, dissemination of knowledge and managerial skills (MOORE, 1996; BONAMIGO et al., 2016).

The lack of improved technology and structure of dairy production system appears as another sector barrier. This lack of technology can impact on industry productivity rates. Since non-use makes them raise production costs, because of the inefficiency of the production process (DOLINSKA et D'AQUINO, 2016; SAENGER et al., 2013; NOVO et al., 2013). These impacts, limiting the dairy sector competitiveness, as well as in the dairy basins business sustainability and/or regions that predominate family agriculture in this activity. One of these limitation consequences is that the producer may end up choosing to leave the field and migrate to urban areas, resulting in the rural exodus.

In relation to milk quality aspects provide the product quality does not create differential and is a source of competitive advantage. As the quality established by law, with the aim of ensuring food safety for consumers. Meet regulatory requirements, the steps of the production process, transport and storage of milk, is a determining factor for a better quality of milk (WINCK, 2009; WINCKLER, 2011; VALEEVA et al., 2007). 
As pressure to mitigate problems related to poor quality of milk delivered by producers, some agribusinesses dairy opted to implement contracts for payment of milk to the producer by the quality of the milk supplied, ie, the higher the quality indices delivered better remuneration generated for the dairy producer (WINCK, 2009; SCHIPMANN et QAIM, 2011), an example of the normally applied criterion is the somatic cell count found in milk.

The lack of milk quality may limit raw milk and/or milk products exportation because they do not meet the minimum specifications for the entry of these products into the destination countries. In addition, we can highlight that this lack of milk quality impacts on the food properties that contain milk, such as vitamins, protein, fat and lactose.

Regarding the productivity limiters, poor organization of activity among producers, can be a barrier, since it is related to the human factor. An example of this occurs in the Brazilian dairy system, where there is a predominance of family agriculture. This requires a better organization of the production chain, because the fact of being familiar limits the activity of accessing resources, technologies, and guidelines of good manufacturing practices (GHOSH et MAHARJAN, 2004; FISCHER et al., 2011).

This problematic in some countries, including Brazil, was overcome by creating producer cooperatives, which facilitates the bargain purchase inputs, allocation of production, and better organization of dairy farming by producers cooperating in this system, and at the same time are suppliers and customers of the cooperative system (CHADDAD, 2007; JUNQUEIRA et GIMENES, 2009).

Moore (1997) considers that each company, by cultural factors wishes to maintain their autonomy. As well as remain reserved about their future plans. To work in a cooperative way, they must balance this desire with the need to work with each other, considering that the coordination between the actors of the business environment generates competitive advantage. In this sense, the business ecosystem is an enabler for a better stakeholders' management which comprise the dairy environment. By having this understanding is it possible to transpose the dairy sector barriers.

\section{FINAL TOUGHTS}

This study aimed to diagnose the barriers of dairy production from the perspective of the business ecosystem. We found three categories of barriers productivity limitations, milk quality deficiency and lack of cooperation between actors of the chain.

Regarding the category lack of cooperation between the actors, the ten identified barriers are linked to limited knowledge and cooperation exchange and, this constraint the development of dairy production. Because without sharing knowledge, tools, procedures, techniques, best practices, investments, opportunities, with the hole ecosystem, they cannot be boosted by the benefits of value co-creation.

We also observed that the barriers linked to quality and productivity can be solved through systemic interaction between the actors in this business environment. The business ecosystem, as its essence, is appropriate to mitigate the barriers found in dairy production. Once it has a systemic look at the whole business environment, the players and their role can be identified. With that information, can be developed strategies for integration between the actors of the ecosystem, for instance universities, research centers, cooperatives, financial agencies, farmers, transporters, among others. The union of all those players can excel the skills, knowledge and process by the complement and interaction between the actors. When using the perspective of the business ecosystem, the system can be seen through an arrangement in which the actors interact with each other to form a business platform. The formation of this platform, is aimed to boost the exchange of knowledge and cocreation among the actors that make up the dairy production environment. This platform can develop a systematic way of exchanging knowledge among all the stakeholders and encourage them to co-creation of value in dairy production.

Based on the barriers presented in our study, government initiatives can be traced to encourage the actors in the dairy ecosystem to form business platform. For instance, the interaction of dairy producers with technological institutes /universities can mitigate the barriers linked to lack of the dairy industry technology.

Regarding the barriers linked to the quality, the cocreation between dairy producers with manufacturers of machinery/equipment for the milking process/handling, can reduce problems related to quality of milk supplied to dairy agribusiness. At this point it is noteworthy that provide milk quality is no longer differential to increase the payment of milk to the producer. Meet the standards of quality and food safety established in legislation is indispensable for the national and/or international market. In this sense, the dairy production system demand actions to incorporate new technologies, so that the producer gets greater economic gains and reduce production costs.

We identified fifteen barriers that are limiting the production and innovation and categorize them into three groups. From this classification, we must plan actions to overcome these barriers. This transposition is essential to the growth and strengthening of the entire dairy ecosystem.

Dairy ecosystem players, when acting in a cooperative way, may form a business platform, in order to boost knowledge, technologies and resources exchange. Once the player acting individually is limited to access these, which can impact on business continuity. 
Based on the barriers faced by this study, it is possible to present some opportunities for future studies. One of them is to make a diagnosis in dairy production in a defined scope, for example, in a region, state or country to recognize the problems encountered and outline actions. Another is to verify the theoretical barriers in practice in order to confirm or refute them. In addition to this, develop a reference model for the formation and management of business platforms in the ecosystem in dairy production and also relate the results in the theory in relation to the practical environment, limited to a geographic region.

\section{ACKNOWLEDGEMENTS}

We the authors would like to thank CAPES (Coordination for the Improvement of Higher Education Personnel) and CNPQ (National Counsel of Technological and Scientific Development) for the scholarships financial support. This was fundamental for the present study development.

\section{REFERENCES}

Bardin, L. (2011). Análise de conteúdo, Lisbon.

Batalha, M. O.; Silva, A. L. (2007). Gerenciamento de sistemas agroindustriais: definições, especificações, especificidades e correntes metodológicas. In: Batalha, M. O. (Coord.). Gestão agroindustrial. 3. ed. São Paulo: Editora Atlas, pp. 1-62.

Bonamigo, A.; Ferenhof, H. A.; Forcellini, F. A. (2016). Applicability analysis of the business ecosystem concept in dairy production based on a systematic literature review. II Simpósio Internacional de Inovação em Cadeias do Agronegócio, Caxias do Sul. Agosto 26, 2016, pp.1-10.

Chaddad, F. R. (2007). Cooperativas no agronegócio do leite: mudanças organizacionais e estratégicas em resposta à globalização. Organizações Rurais \& Agroindustriais, Vol. 9, No. 1, pp. 69-78.

Colurcio, M.; Wolf, P.; Kocher, P. Y.; Spena, T. R. (2012). Asymmetric relationships in networked food innovation processes. British Food Journal. Vol. 114, No. 5, pp. 702-727.

Dolinska, A.; d'Aquino, P. (2016). Farmers as agents in innovation systems. Empowering farmers for innovation through communities of practice. Agricultural Systems, Vol. 142 , No. 1, pp. 122-130.

Eastwood, C. R.; Chapman, D. F.; Paine, M. S. (2012). Networks of practice for co-construction of agricultural decision support systems: Case studies of precision dairy farms in Australia. Agricultural Systems Vol. 108, No. 1, pp. 10-18.

FAO (2016). Mil production. Food and Agriculture Organization of the United Nations, Available in: <http:// www.fao.org/agriculture/dairy-gateway/milk-production/ en/\#.VwZh9aQrLIW> Accessed in: 07/04/16.

Fischer, A.; Junior, S. S.; Sehnem, S.; Bernardi, I. (2011). Produção e produtividade de leite do Oeste catarinense. Revista de administração, contabilidade e economia, Vol.10, No. 2, pp. 337-362.

Galateanu, E.; Avasilcai, S. (2013). Business Ecosystems Arhitecture. Annals of the Oradea University, Vol. 22, No. 1, pp. 79-84.

Ghosh, A. K.; Maharjan, K. L. (2004). Development of Dairy Cooperative and Its Impacts on Milk Production and Household Income: A Study on Bangladesh Milk Producers' Cooperative Union Limited. Journal of International Development and Cooperation, Vol. 10, No. 2, pp. 193-208.

Jesson, J. K., Matheson, L.; Lacey, F. M. (2011). Doing Your Literature Review: Traditional and Systematic Techniques, Sage, Los Angeles.

Junqueira, C. P.; Gimenes, R. M. T. (2009). Cooperativa Agroindustrial Lar: conciliando a doutrina cooperativista e a competitividade de mercado. Revista Ciências Empresariais Unipar, Vol. 10, No. 2, pp. 315-345.

Kilelu, C.W.; Klerkx, L.; Leeuwis, C. (2013). Unravelling the role of innovation platforms in supporting co-evolution of innovation: Contributions and tensions in a smallholder dairy development programme. Agricultural Systems. Vol. 118, No. 1, pp. 65-77.

Lamprinopoulou, C.; Renwick, A.; Klerkx, L.; Hermans, F.; Roep, D. (2014). Application of an integrated systemic framework for analysing agricultural innovation systems and informing innovation policies: Comparing the Dutch and Scottish agrifood sectors. Agricultural Systems, Vol. 129, No. 1, pp. 40-54.

McNulty, T.; Zattoni, A.; Douglas, T. (2013). Developing corporate governance research through qualitative methods: a review of previous studies, Corporate Governance: An International Review, Vol. 21, No. 2, 183-198.

Moore, J. (1993). Predators and Prey: The New Ecology of Competition, Harvard Business Review, Vol. 4, No. 1, pp.1323.

Novo, A.M.; Slingerland, M.; Jansen, K.; Kanellopoulos, A.; Giller, K. E. (2013). Feasibility and competitiveness of intensive smallholder dairy farming in Brazil in comparison with soya and sugarcane: Case study of the Balde Cheio Programme. Agricultural Systems, Vol. 121, No. 1, pp.63-72.

Peltoniemi, M.; Vuori, E. (2004). Business ecosystem as the new approach to complex adaptive business environments. In Proceedings of eBusiness research forum; Vol. 18 pp. 267281. 
Rodrigues, L. G.; Alban, L. (2013). Tecnologias de produção de leite utilizadas no Extremo-Oeste Catarinense. Revista de administração, contabilidade e economia, Vol.12, No. 1, pp. 171-198.

Saenger, C.; Qaim, M.; Torero, M.; Viceisza, A. (2013). Contract farming and smallholder incentives to produce high quality: experimental evidence from the Vietnamese dairy sector. Agricultural Economics, Vol. 44, No. 3, pp.297-308.

Schipmann, C.; Qaim, M. (2011). Supply chain differentiation, contract agriculture, and farmers' marketing preferences: The case of sweet pepper in Thailand. Food Policy, Vol. 36, No. 5, pp. 667-677.

Smits, R.; Kuhlmann, S. (2004). The rise of systemic instruments in innovation policy. International Journal of Foresight and Innovation Policy, Vol. 1, No. 1-2, pp. 4-32.

Somda, J.; Kamuanga, M.; Tollens, E. (2005). Characteristics and economic viability of milk production in the smallholder farming systems in The Gambia. Agricultural Systems, Vol. 85 , No. 1 , pp. $42-58$

Valeeva, N. I.; Huirne, R. B. M.; Meuwissen, M. P. M.; Oude Lansink, A. G. J. M. (2007). Modeling farm-level strategies for improving food safety in the dairy chain. Agricultural Systems Vol. 94, No. 2, pp. 528-540.

Winck, C. A. (2013). Impactos do pagamento pela qualidade na cadeia produtiva do leite na região Oeste de Santa Catarina (Doctor Thesis). Agronegócios, University Federal of Rio Grande do Sul, pp. 122.

Winckler, N. C. (2011). A coopetição entre propriedades rurais da cadeia produtiva do leite no Oeste Catariense (Master Thesis). Agronegócios, University Federal of Rio Grande do Sul, pp. 91.

Xhoxhi, O.; Pedersen, S. M.; Lind, K. M.; Yazar, A. (2014). The Determinants of Intermediaries' Power over Farmers' Margin-Related Activities: Evidence from Adana, Turkey. World Development Vol. 64, No. 1, pp. 815-827. 